\title{
Structural and vibrational spectroscopic studies of new phases with sillenite type in the system $\mathrm{Bi}_{2} \mathrm{O}_{3}-\mathrm{In}_{2} \mathrm{O}_{3}-\mathrm{MgO}$
}

\author{
Hajar Ait Oulahyane*, Abdeslam Chagraoui, Leila Loubbidi, Lamia Bourja, Omar Ait Sidi Ahmed and \\ Abdelmjid Tairi
}

Laboratory of Analytical Chemistry and Physico-chemistry of Materials (LCAPM), Faculty of Sciences Ben M'Sik, University Hassan II, Casablanca, Morocco

\begin{abstract}
The anion and cation deficient phase $\mathrm{Bi} 0.95 \mathrm{In} 0.05 \mathrm{O}_{1.5}\left(\mathrm{Bi}_{1.9} \mathrm{In}_{0.1} \mathrm{O}_{3}\right)$ was synthesized and experimentally investigated using X-ray diffraction and vibrational spectroscopy (Infrared and Raman). The non-stoichiometric phases are similar to sillenite family type $\gamma \mathrm{Bi} 2 \mathrm{O} 3$ and crystallize in the $\mathrm{I} 23$ space group. The crystal structure was determined by full profile Rietveld analysis of the powder diffractogram. It is formed by a sequence of $\mathrm{BiO}_{5} \mathrm{E}$ polyhedra (E lone pair of bismuth) and $\mathrm{MO}_{4}$ polyhedra $(\mathrm{M}=\mathrm{In}, \mathrm{Mg})$. The set of $\mathrm{MO}_{4}$ polyhedra are localized in cavities generated by $\mathrm{BiO}_{5} \mathrm{E}$ polyhedra. The vibrational spectroscopic study revealed the existence of three regions; low, intermediate and high-frequency region. They are attributed to Bi-O stretching mode, In / Mg$\mathrm{O}$ vibrations and cationic displacements respectively.
\end{abstract}

Key words: Sillenite; X-ray diffraction; IR; RAMAN.

\section{Introduction}

Recently, materials having elements with outer electronic configuration $\mathrm{ns}^{2}$, particularly sillenite phases, have been extensively studied because of their remarkable properties such as; piezoelectricity, optoelectronics, photocatalysis, dielectricity ... ${ }^{1-8}$.

Indeed the sillente phase is isolated for the first time by Silen in 1937 and admits as formula $\mathrm{Bi}_{12} \mathrm{MO}_{20}$ $(\mathrm{M}=\mathrm{Si}, \mathrm{Ti}, \mathrm{Ge})^{9}$. Several studies have been conducted, in particular on the crystalline structure, such as those of Levin and Roth ${ }^{10}$, and Radev et al. ${ }^{11}$ that have determined the crystal structure of $\mathrm{Bi}_{12}\left(\mathrm{Bi}_{2 / 3}\right.$ $\left.\mathrm{Zn}_{1 / 3}\right) \mathrm{O}_{19.33}$ and $\mathrm{Bi}_{12}\left(B i_{0.5}^{3+} F e_{0.5}^{3+}\right) \mathrm{O}_{19.5}$ by neutron diffraction.

The stability of sillenite phase is achieved by adding small amounts of desired oxides such as $\mathrm{Li}_{2} \mathrm{O}, \mathrm{ZnO}$, $\mathrm{Ga}_{2} \mathrm{O}_{3}, \quad \mathrm{As}_{2} \mathrm{O}_{5}, \quad \mathrm{P}_{2} \mathrm{O}_{5}, \quad \mathrm{~V}_{2} \mathrm{O}_{5} \ldots$ without exceeding $8 \mathrm{~mol} \%{ }^{12,13}$. Generally, sillenites are stoichiometric or sub-stoichiometric. The defects appear in both cationic and anionic sub-lattices ${ }^{14}$. Several structural models were established ${ }^{15}$. The models proposed by Radev et al and confirmed later by J.C Champarnaud 16,17 seem more convincing. These models revealed that sillenite is related to the $\gamma$ - $\mathrm{Bi} 2 \mathrm{O} 3$ variety and is written as $\mathrm{Bi}_{12}\left(\left(\mathrm{BiO}_{3} \square\right)_{0.8}\left(\square \mathrm{O}_{4}\right)_{0.2}\right) \mathrm{O}_{16}=\mathrm{Bi}_{12} \mathrm{Bi}_{0.8}$ $\mathrm{O}_{19.2 \text {. }}$

The sillenite compounds $\mathrm{Bi}_{12} \mathrm{M}_{\mathrm{x}} \mathrm{O}_{20}$ crystallize in the I23 space group. The crystalline structure is formed

*Corresponding author: Hajar Ait Oulahyane

Email address: hajar.aitoulahyane@gmail.com

DOI: http://dx.doi.org/10.13171/mjc101020011123hao by a three-dimensional sequence of $\mathrm{BiO}_{5} \mathrm{E}$ polyhedra (E lone pair). These polyhedra share the edges and the vertices by $\mathrm{M}^{\mathrm{n}+} \mathrm{O}_{4}$ tetrahedra. The $\mathrm{M}^{\mathrm{n}+}$ cation may be a tetravalent element in the case of stoichiometric sillenite or a combination of elements with an average value of four.

In the present work, On the one hand, the new phases isolated within the $\mathrm{Bi}_{2} \mathrm{O}_{3}-\mathrm{In}_{2} \mathrm{O}_{3}-\mathrm{MgO}$ system have been studied and identified as belonging to sillenite family. On the other hand, these phases were examined using Infrared and Raman spectroscopy techniques. The X-ray analysis was performed using the Rietveld structure refinement by full prof program ${ }^{18}$. The influence of dopant content; indium (single doping) or In and $\mathrm{Mg}$ (codoping) on the sillenite structural features has been discussed.

\section{Experimental section}

\subsection{Preparation}

The synthesized compounds have been stabilized with a solid-state method using the appropriate quantities of highly pure oxides powder $\alpha \mathrm{Bi}_{2} \mathrm{O}_{3}, \mathrm{MgO}$ and $\mathrm{In}_{2} \mathrm{O}_{3}$ with hight purity (Aldrich brand). These oxides were heated at successively higher temperatures $700^{\circ} \mathrm{C}$ (24h) and $800^{\circ} \mathrm{C}(24 \mathrm{~h})$ with several intermediate grindings and followed by quenching.

\subsection{X-ray diffraction}

The final products have been monitored by X-ray powder diffraction (XRD) using a Philips X'Pert PRO

Received October 17, 2019

Accepted December 3, 2019

Published February 1, 2020 
diffractometer and Cu-K-alpha $(\lambda=1.5406 \AA)$ radiation. The structural refinements were undertaken from the powder data. The patterns were scanned through steps of $0.02^{\circ}(2 \theta)$, between $10^{\circ}$ and $70^{\circ}(2 \theta)$ with a fixed time counting of $60 \mathrm{~s}$. The study of the structure is conducted by analyzing the profile of $\mathrm{X}$-ray diffraction diagrams of powder with the program Fullprof 18 using the pseudo-Voight function.

\subsection{IR spectrum}

IR spectrum was recorded by using Bruker Tensor 27 with prepared pellets $(1 \mathrm{mg}+99 \mathrm{mg} \mathrm{KBr})$ in a frequency range of 400-4000 $\mathrm{cm}^{-1}$.

\subsection{Raman Spectrum}

Raman spectrum was recorded by using DXR RAMAN spectrometer with exciter wavelength of $663 \mathrm{~nm}$ and a power of $6 \mathrm{MW}$.

\section{Results and discussion}

\subsection{Structural studies}

In this paper, the structural analysis was focalized on three compositions, namely $\mathrm{Bi}_{0.95} \mathrm{In}_{0.05} \mathrm{O}_{1.5}$, $\mathrm{Bi}_{0.90} \mathrm{In}_{0.05} \mathrm{Mg}_{0.05} \mathrm{O}_{1.475}$ and $\mathrm{Bi}_{0.80} \mathrm{In}_{0.1} \mathrm{Mg}_{0.1} \mathrm{O}_{1.45}$. We present $\mathrm{Bi}_{0.95} \mathrm{In}_{0.05} \mathrm{O}_{1.5}\left(\mathrm{Bi}_{1.9} \mathrm{In}_{0.1} \mathrm{O}_{3}\right)$ as an example.
The results of the other compositions will be published later.

On the basis of $\gamma \mathrm{Bi}_{2} \mathrm{O}_{3}$ phase structure previously determined by Radev ${ }^{11}$, we carried out our structural study by distributing the cations on the possible sites. The chemical form of this compound can be written: $\left.\mathrm{Bi}_{12}\left[\left(\mathrm{Bi}_{0.16} \mathrm{In}_{0.64}\right) \square \mathrm{O}_{3}\right)_{0.8}\left(\square \mathrm{O}_{4}\right)_{0.2}\right] \mathrm{O}_{16}$. Table 1 contains the experimental conditions and the structural parameters of this composition.

\section{- First case:}

$\mathrm{Bi}_{1} \rightarrow 24 \mathrm{f}, \mathrm{Bi}_{2}$, In $\rightarrow 2 \mathrm{a}, \mathrm{O}_{1} \rightarrow 24 \mathrm{f}, \mathrm{O}_{2} \rightarrow 8 \mathrm{c}, \mathrm{O}_{3} \rightarrow 8 \mathrm{c}$ Many refinement cycles are performed and led to good reliability values (Table 1). However, the calculated distances of coordination polyhedra are incorrect.

\section{- Second case:}

$\mathrm{Bi}_{1} \rightarrow 24 \mathrm{f}, \mathrm{In} \rightarrow 2 \mathrm{a}, \mathrm{O}_{1} \rightarrow 24 \mathrm{f}, \mathrm{O}_{2} \rightarrow 8 \mathrm{c}, \mathrm{O}_{3} \rightarrow 8 \mathrm{c}$

The final refinement led to an occupancy rate of $\mathrm{Bi}$ atom $>1$ on $24 \mathrm{f}$ site, which contradicts the total filling on this site.

\section{- Third case:}

The atoms $\mathrm{Bi}$ and In, initially occupying the sites $24 \mathrm{f}$ and $2 \mathrm{a}$ respectively (according to the first case), were redistributed in the nearby sites admitting, therefore, the atomic positions given in Table 2 .

Table 1. Experimental details and crystallographic data of $\mathrm{Bi}_{0.95} \operatorname{In}_{0.05} \mathrm{O}_{1.5}$.

\begin{tabular}{|c|c|c|c|c|c|c|c|c|c|}
\hline SG & $\mathbf{a}(\mathbf{A})$ & angular range & $\begin{array}{c}\text { Step of } \\
\text { measure }\end{array}$ & $\begin{array}{c}\text { Number of } \\
\text { refined } \\
\text { parameters }\end{array}$ & Rp & Rwp & Rexp & $\begin{array}{c}\mathbf{R}_{\mathbf{B}} \\
(\boldsymbol{\%})\end{array}$ & $\begin{array}{c}\mathbf{R}_{\mathbf{F}} \\
(\boldsymbol{\%})\end{array}$ \\
\hline $\mathbf{I 2 3}$ & $10.1089(3)$ & $10^{\circ}<2 \theta<70^{\circ}$ & $0.02^{\circ} / \mathrm{min}$ & 89 & 21.6 & 25.5 & 18.8 & 4.99 & 4.46 \\
\hline
\end{tabular}

The final refinement seems to be in good agreement

with the occupancy rates and the calculated distances (Tables 2 and 3 ).

Table 1. Refined atomic coordinates and thermal agitation factors of $\mathrm{Bi}_{0.95} \operatorname{In}_{0.05} \mathrm{O}_{1.5}$

\begin{tabular}{|c|c|c|c|c|c|c|}
\hline Atomes & Symmetry & $\mathbf{x}$ & $\mathbf{y}$ & $\mathbf{Z}$ & Biso & Occ \\
\hline $\mathbf{B i}_{\mathbf{1}}$ & $24 \mathrm{f}$ & $0.176(3)$ & $0.3170(2)$ & $0.0168(3)$ & $1.151(3)$ & 1.000 \\
\hline $\mathbf{B i} \mathbf{1}_{\mathbf{2}}$ & $2 \mathrm{a}$ & 0.005 & 0.005 & 0.005 & 0.200 & $0.008(9)$ \\
\hline $\mathbf{I n}$ & $8 \mathrm{c}$ & 0.000 & 0.000 & 0.000 & 0.200 & $0.010(7)$ \\
\hline $\mathbf{O}_{\mathbf{1}}$ & $24 \mathrm{f}$ & $0.139(3)$ & $0.258(3)$ & $0.506(4)$ & 0.200 & 1.000 \\
\hline $\mathbf{O}_{2}$ & $8 \mathrm{c}$ & $0.201(4)$ & $0.201(4)$ & $0.201(4)$ & 0.200 & 0.300 \\
\hline $\mathbf{O}_{3}$ & $8 \mathrm{c}$ & $0.888(4)$ & $0.888(4)$ & $0.888(4)$ & 0.200 & 0.300 \\
\hline
\end{tabular}


Table 2. Main interatomic distances $(\AA)$, angles $\left(^{\circ}\right)$ and bond valences in $\mathrm{Bi}_{0.95} \operatorname{In}_{0.05} \mathrm{O}_{1.5}$.

\begin{tabular}{|c|c|c|c|c|c|c|}
\hline $\mathbf{B} \mathbf{i}^{(\mathbf{1})}$ & $\mathbf{O} 1^{(1)}$ & $\mathbf{O} 2^{(1)}$ & $\mathbf{O 3}^{(1)}$ & $04^{(2)}$ & $\mathrm{O5}^{(3)}$ & Valence \\
\hline $\mathbf{O 1} 1^{(1)}$ & $2.42(3)$ & $2.02(3)$ & $2.89(4)$ & $2.216(3)$ & $2.535(2)$ & 0.411 \\
\hline $\mathbf{O 2} 2^{(1)}$ & $90(2)$ & $2.52(3)$ & $2.89(4)$ & $2.216(3)$ & $2.535(2)$ & 0.314 \\
\hline $\mathbf{O 3}^{(\mathbf{1})}$ & $71.3(2)$ & $125(2)$ & $2.02(3)$ & $2.216(3)$ & $2.535(2)$ & 1.212 \\
\hline $04^{(2)}$ & $87.0(1)$ & $149.6(2)$ & $75.0(2)$ & $2.216(3)$ & $2.535(2)$ & 0.719 \\
\hline O5 ${ }^{(3)}$ & $174.9(2)$ & $110.3(1)$ & $84.5(1)$ & $91.6(3)$ & $2.535(2)$ & 0.303 \\
\hline & & & & & & 2.959 \\
\hline \multicolumn{2}{|l|}{$\mathbf{B} \mathbf{i}^{(2)}$} & $\mathbf{O 1} 1^{(3)}$ & $\mathbf{O} 2^{(3)}$ & $\mathbf{O 3}^{(3)}$ & O4 $4^{(3)}$ & Valence \\
\hline \multicolumn{2}{|l|}{ O1 $1^{(3)}$} & $2.039(9)$ & $1.92503(3)$ & $1.92503(3)$ & $1.92503(3)$ & 1.189 \\
\hline \multicolumn{2}{|l|}{$\mathbf{O} 2^{(3)}$} & $107.01(4)$ & $1.92(5)$ & $1.92503(3)$ & $1.92503(3)$ & 1.579 \\
\hline \multicolumn{2}{|l|}{$\mathbf{O 3}^{(3)}$} & $107.01(4)$ & 107.01(4) & $1.92(5)$ & $1.92503(3)$ & 1.579 \\
\hline \multicolumn{2}{|l|}{$O 4^{(3)}$} & $107.01(4)$ & $107.01(4)$ & $107.01(4)$ & $1.925(3)$ & 1.579 \\
\hline & & & & 5.296 \\
\hline \multicolumn{2}{|l|}{ In } & $\mathbf{O 1} 1^{(3)}$ & $\mathbf{O} 2^{(3)}$ & $\mathbf{O 3}^{(3)}$ & $04^{(3)}$ & Valence \\
\hline \multicolumn{2}{|l|}{$01^{(3)}$} & $1.952(4)$ & $1.95244(3)$ & $1.95244(3)$ & $1.95244(3)$ & 0.874 \\
\hline \multicolumn{2}{|l|}{$\mathbf{O} 2^{(3)}$} & $109.4(7)$ & $1.952(4)$ & $1.95244(3)$ & $1.95244(3)$ & 0.874 \\
\hline \multicolumn{2}{|l|}{$\mathbf{O 3}^{(3)}$} & $109.4(7)$ & $109.4(7)$ & $1.952(4)$ & $1.95244(3)$ & 0.874 \\
\hline \multicolumn{2}{|l|}{ O4 $4^{(3)}$} & $109.4(7)$ & $109.4(7)$ & $109.4(7)$ & $1.952(4)$ & 0.874 \\
\hline
\end{tabular}

The experimental, calculated X-ray diffraction patterns and differential spectrum obtained by using

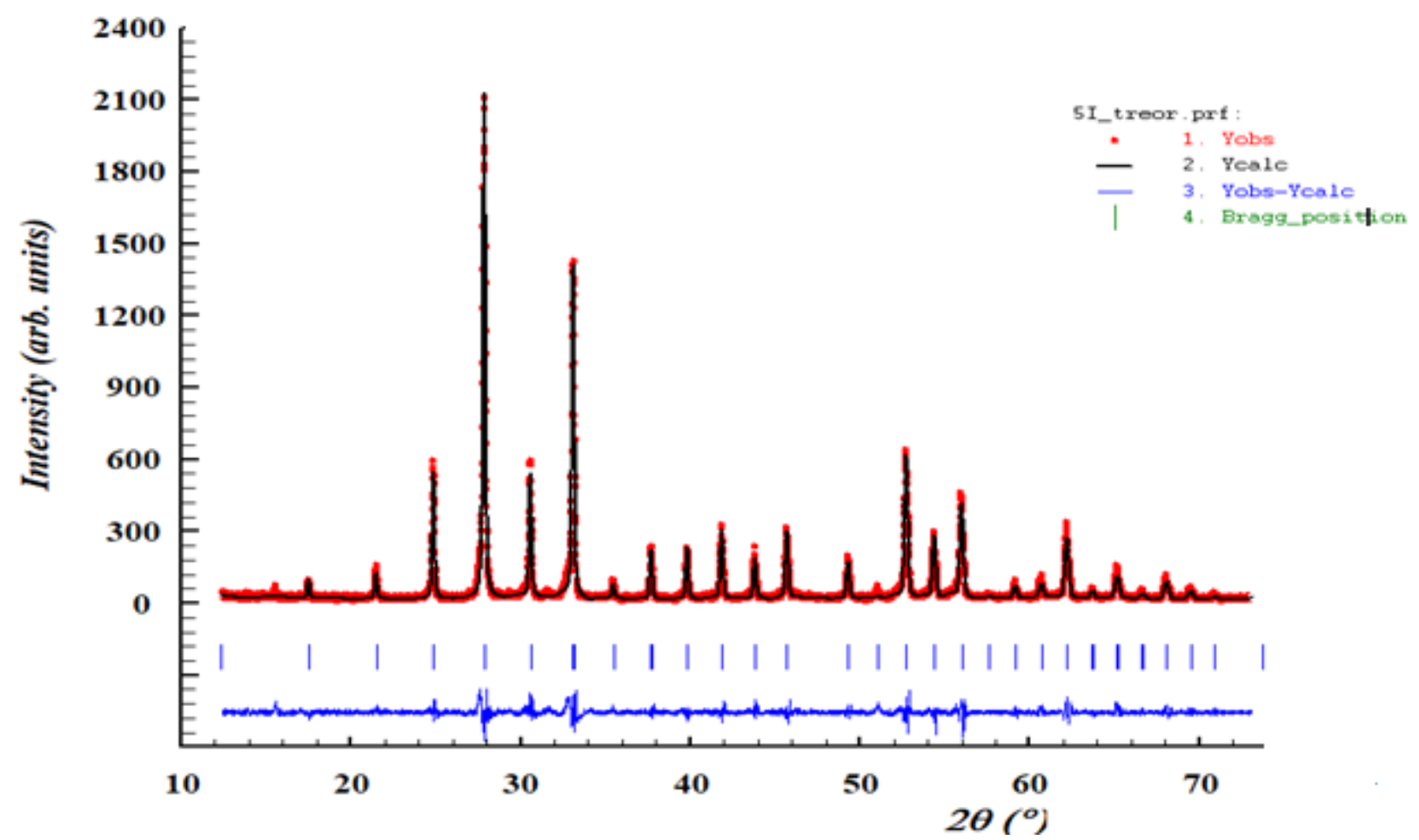

Figure 1. Observed, calculated and difference powder XRD patterns of $\mathrm{Bi}_{0.95} \operatorname{In}_{0.05} \mathrm{O}_{1.5}$ 
3.2. Structure

illustrated in Figure 2.

The structure of $\mathrm{Bi}_{0.95} \operatorname{In}_{0.05} \mathrm{O}_{1.5}\left(\mathrm{Bi}_{1.9} \operatorname{In}_{0.1} \mathrm{O}_{3}\right)$ is

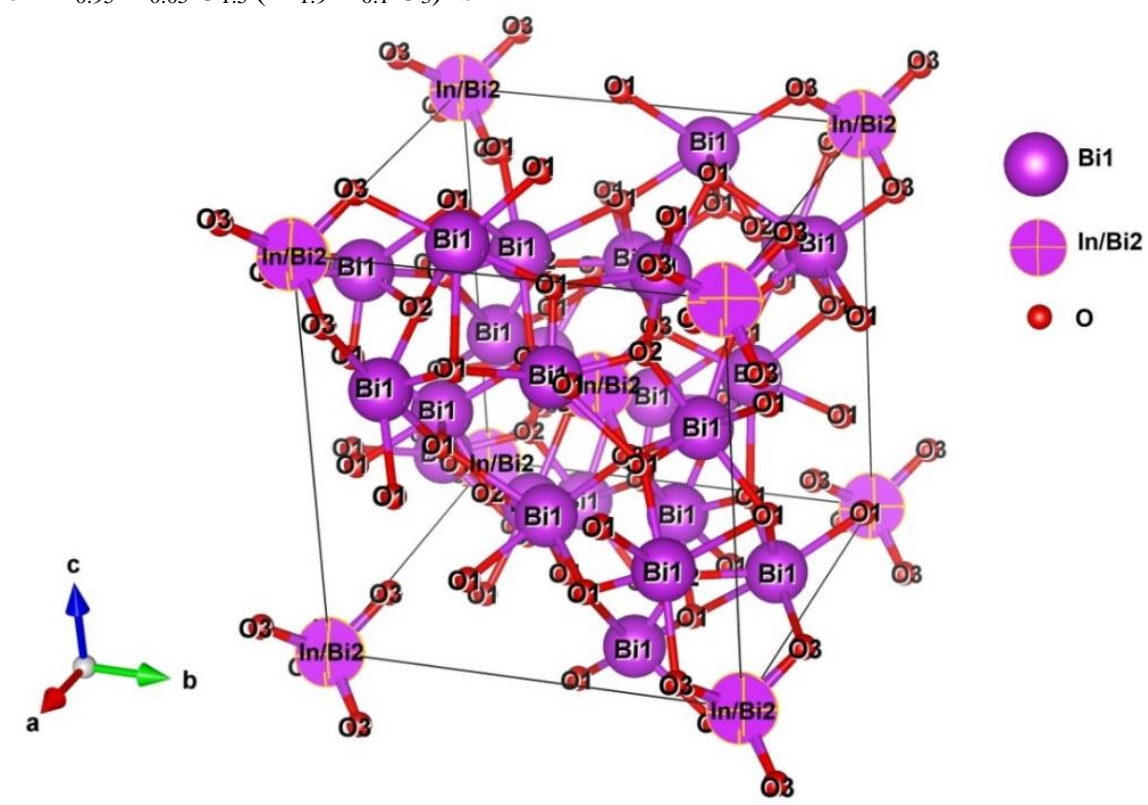

Figure 2. Three-dimensional view of $\mathrm{Bi}_{0.95} \operatorname{In}_{0.05} \mathrm{O}_{1.5}$

Note: We have simplified the structure representation by placing In/Bi2 on the same site.
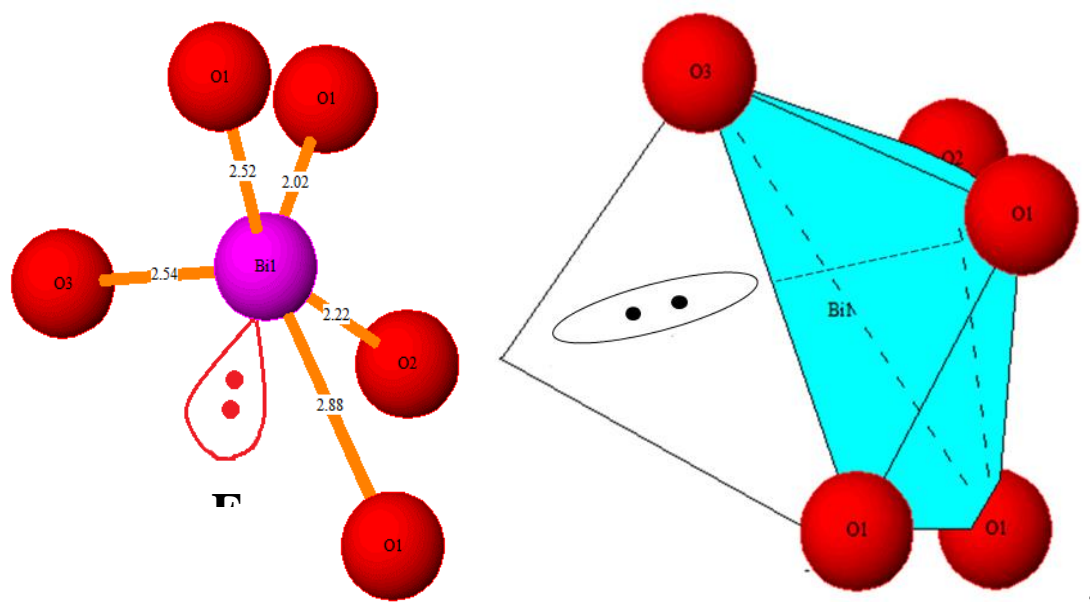

Figure 3. The octahedral arrangement of $\mathrm{Bi}_{1}{ }^{3+}$ with five atoms of oxygen and the lone pair of bismuth
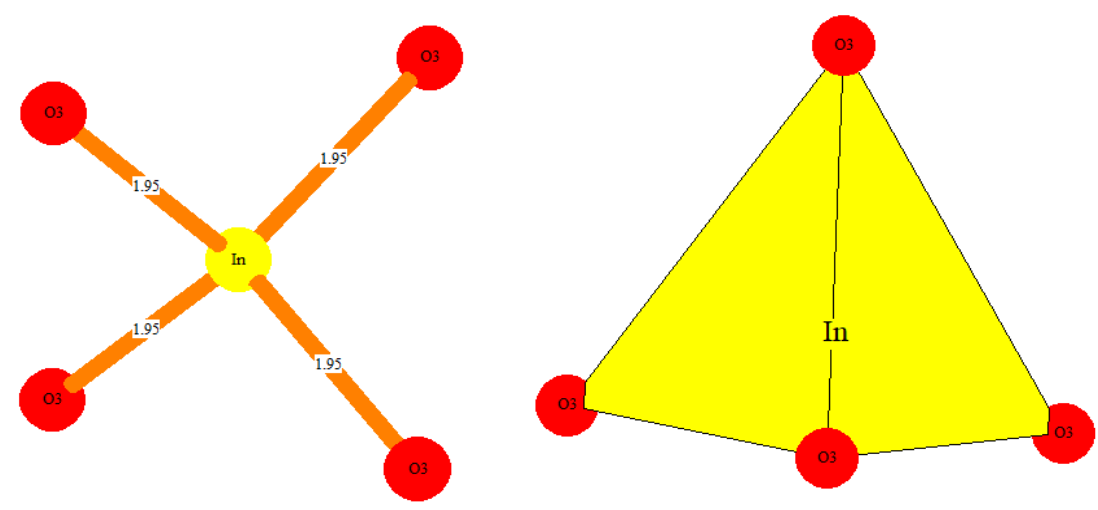

Figure 4. View of the $\mathrm{In}^{3+}$ environment 


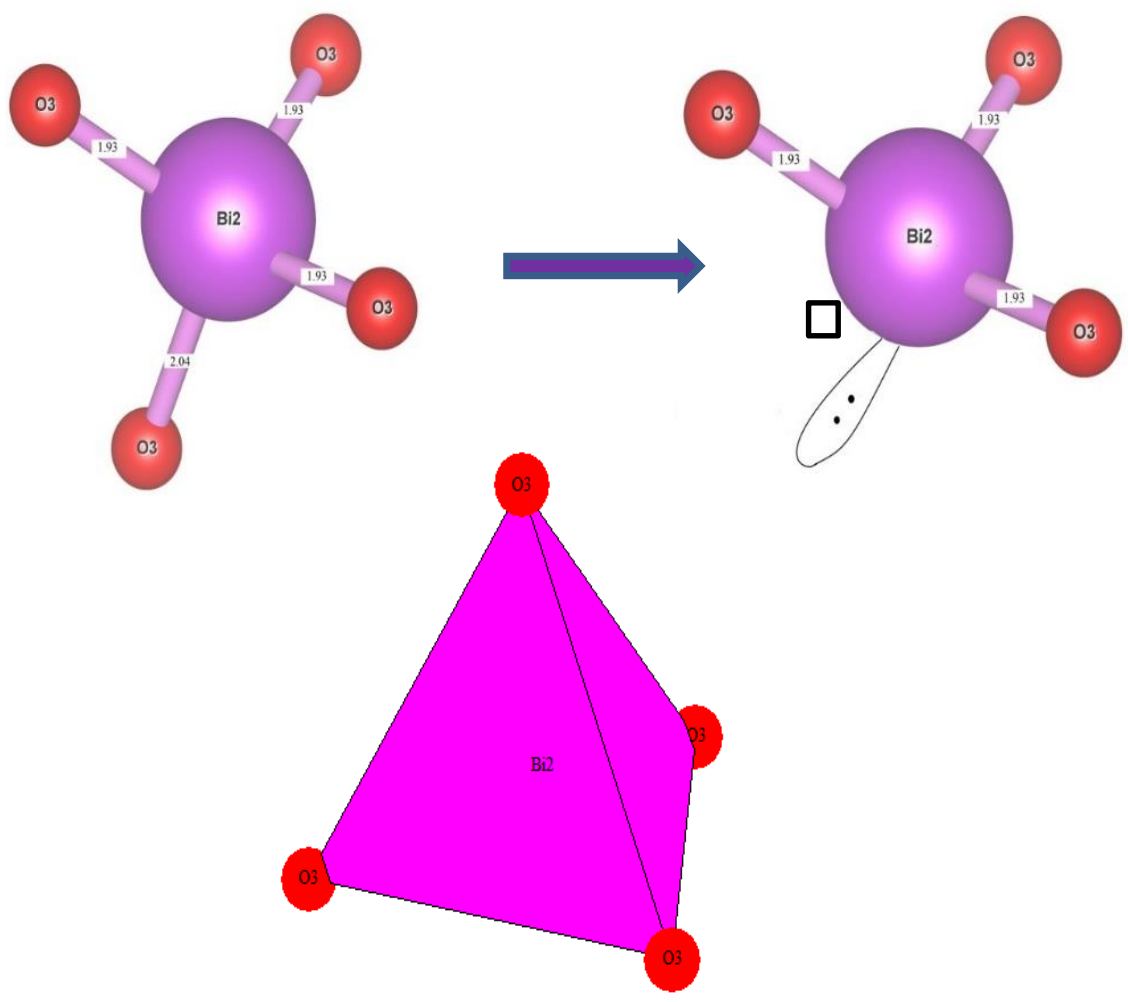

Figure 5. View of the $\mathrm{Bi}_{2}{ }^{3+}$ environment

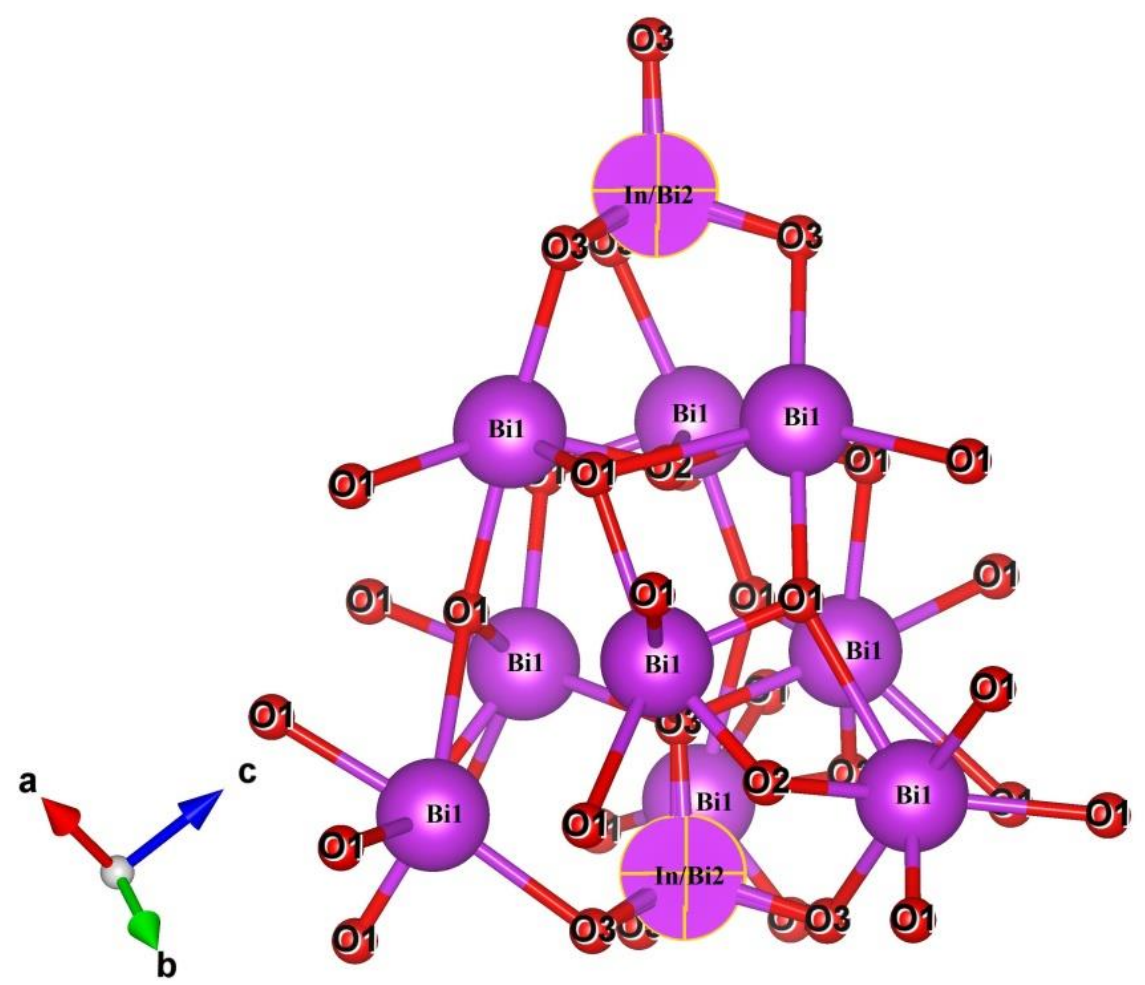

Figure 6. Three-dimensional environment of octahedron $\mathrm{Bi}_{1} \mathrm{O}_{5} \mathrm{E}$ and tetrahedron $\left(\mathrm{In} / \mathrm{Bi}_{2}\right) \mathrm{O}_{4}$ 


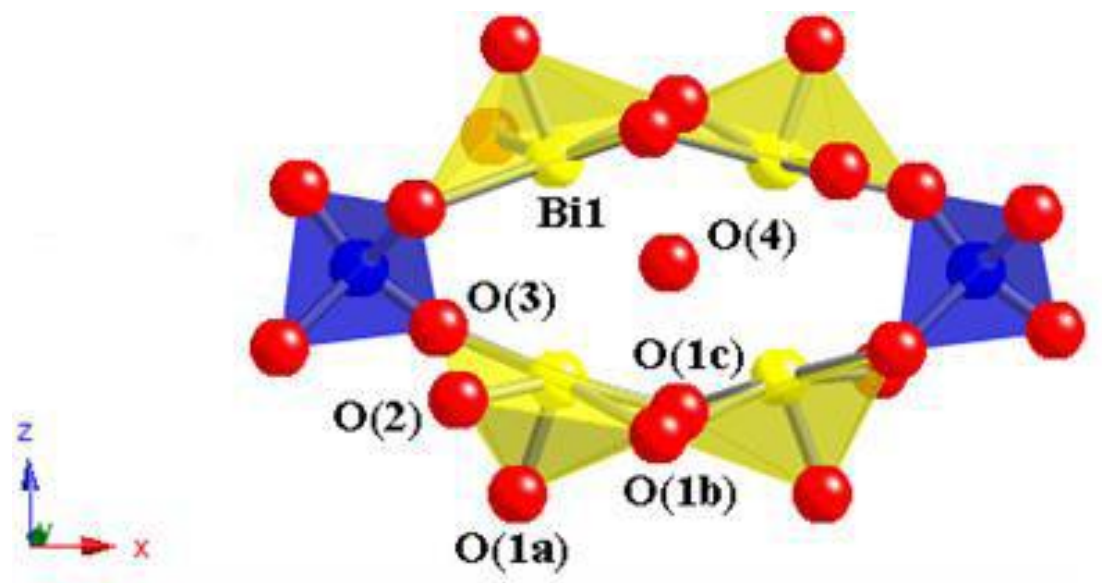

Figure 7. Ideal sillenite structure $\left(\mathrm{Bi}_{12} \mathrm{MO}_{20}\right)^{19}$

The structure consists of a three-dimensional sequence of $\mathrm{BiO}_{5} \mathrm{E}$ (E lone pair) polyhedra (Fig.3) stereochemically active of $\mathrm{Bi}^{3+}$ sharing alternatively edges and vertices.

This lattice system contains tetrahedral cavities occupied by $\mathrm{Bi}^{3+} / \mathrm{In}^{3+}$. The substitution of bismuth by indium of a smaller size will cause a decrease of lattice parameter a $\left(\gamma \mathrm{Bi}_{2} \mathrm{O}_{3}=10.25 \AA\right)$ to $10.10 \AA$.

Some changes have been observed in this structure in comparison with the ideal sillenite structure $\mathrm{Bi}_{12} \mathrm{MO}_{20}$ $\left(\mathrm{Bi}_{12} \mathrm{SiO}_{20}\right.$ ) (Fig.7).

These modifications are manifested by a mutual displacement of $\mathrm{Bi}$ and $\mathrm{In}$ atoms and also oxygen atoms located in the equatorial plane of $\mathrm{BiO}_{5} \mathrm{E}$ polyhedra (Fig. 6). Three types of polyhedra surrounding $\mathrm{Bi}^{3+}(24 \mathrm{f}$ site $)$ are envisaged.

- $\mathrm{Bi}_{1} \mathrm{O}_{5} \mathrm{E}$ environment (Fig.3) is a distorted polyhedra. Bi-O distances vary from $2.02 \AA$ to $2.88 \AA$; the average distance $\mathrm{Bi}-\mathrm{O}$ is of the order of $2.43 \AA$ as established by Shannon ${ }^{20}$ $\mathrm{RBi}^{3+}+\mathrm{RO}^{2-}=1.03+1.40 \AA$.
- $\mathrm{Bi}_{2} \mathrm{O}_{4}$ and $\mathrm{InO}_{4}$ polyhedra: This type of polyhedron is similar to that encountered for many compounds of sillenite structure ${ }^{21}$.

$\mathrm{Bi}_{2}$ atom is surrounded by 4 oxygens at distances varying between $1.93 \AA$ and $2.04 \AA$ (Fig.5). The longest distance $\mathrm{Bi}-\mathrm{O}_{3}$ leads to a modification of the lone pair $\mathrm{E}$ orientation on the one hand and the environment of the connected coordination polyhedra on the other hand.

The $\mathrm{Bi} / \mathrm{In}$ environment is a regular tetrahedra, as shown in Figures 5 and 6, the In- $\mathrm{O}_{3}$ distance is $1.95 \AA$. The distribution of $\mathrm{Bi}_{2}{ }^{3+} / \mathrm{In}^{3+}$ on the tetra $8 \mathrm{c}$ and $2 \mathrm{a}$ sites, respectively, generates the creation of anionic vacancies. If this bond is excluded, the environment $\mathrm{Bi}_{2} \mathrm{O}_{3} \mathrm{E}$ will be surrounded by three oxygens and $\mathrm{E}$. The lone pair $\mathrm{E}$ is directed to the missing vertex of the $\mathrm{Bi}_{2} \mathrm{O}_{3} \mathrm{E}$ tetrahedra.

Furthermore, the existence of anionic and cationic vacancies in $8 \mathrm{c}$ site leads to changes in bond lengths within the polyhedra in $\mathrm{Bi}_{12} \mathrm{O}_{16}$ lattice.

In Table 4, we have grouped the main distances obtained in certain sillenite phases $\left(\mathrm{Bi}_{12} \mathrm{GeO}_{20}\right.$ and $\left.\gamma \mathrm{Bi}_{2} \mathrm{O}_{3}\right)$ compared to the distance of the new phase isolated in the $\mathrm{Bi}_{2} \mathrm{O}_{3}-\mathrm{In}_{2} \mathrm{O}_{3}-\mathrm{MgO}$. system

Table 4. Comparison of bismuth coordination polyhedra in $\mathrm{Bi}_{12} \mathrm{GeO}_{20}, \gamma \mathrm{Bi}_{2} \mathrm{O}_{3}$ and $\mathrm{Bi}_{0.95} \mathrm{In}_{0.05} \mathrm{O}_{1.5}$.

\begin{tabular}{|c|c|c|c|}
\hline & $\mathbf{B i}_{\mathbf{1} 2} \mathbf{G e O}_{\mathbf{2 0}}$ & $\gamma \mathbf{B i}_{\mathbf{2}} \mathbf{O}_{\mathbf{3}}$ & $\mathbf{B i}_{\mathbf{1} .9} \mathbf{I n}_{\mathbf{0 . 1}} \mathbf{O}_{\mathbf{3}}$ \\
\hline Bi-O1 & 2.072 & 2.045 & 2.023 \\
\hline Bi-O1 & 2.221 & 2.402 & 2.423 \\
\hline Bi-O1 & 2.622 & 2.456 & 2.523 \\
\hline Bi-O2 & 2.2141 & 2.2788 & 2.216 \\
\hline Bi-O3 & 2.6241 & 2.561 & 2.535 \\
\hline
\end{tabular}

\subsection{Raman spectroscopy analysis}

Raman spectrum of the crystal $\mathrm{Bi}_{0.95} \mathrm{In}_{0.05} \mathrm{O}_{1.5}$ is illustrated in Figure.8. We have also reported the Raman spectrum of $\mathrm{Bi}_{12} \mathrm{TiO}_{20}$ as a comparison (Table 5). The spectrum was recorded in $100-800 \mathrm{~cm}^{-1}$ spectral range at room temperature. The attribution of Raman peaks was based on previous work ${ }^{22}$. At first glance, the spectra are broadly comparable to the $\mathrm{Bi}_{12} \mathrm{TiO}_{20}$ spectrum with a slight difference in intensities. This difference seems to be due to the doping elements In and $\mathrm{Mg}$ on the one hand and the other hand, to the interaction of $\mathrm{BiO}_{5}$ polyhedra with their counterparts In / $\mathrm{Mg} \mathrm{O}_{4}$. 
Table 5. Attribution of observed Raman peaks for $\mathrm{Bi}_{0.95} \operatorname{In}_{0.05} \mathrm{O}_{1.5}$ spectrums.

\begin{tabular}{|c|c|c|c|}
\hline $\begin{array}{l}\text { Peak's } \\
\text { number }\end{array}$ & $\begin{array}{c}\text { Bio. } .95 \text { In } 0.05 \\
\text { O1.5 }_{1.5}\end{array}$ & $\underset{\text { mode }^{22}}{\text { Symmetry }}$ & Type of vibration 22,24 \\
\hline 1 & 48.37 & $\mathrm{~T}$ & $\mathrm{Bi}$, Ti and $\mathrm{Mg}$ vibrations \\
\hline 2 & 72.54 & $\mathrm{E}$ & Stretching vibrations $\mathrm{Bi}, \mathrm{O}_{2}$ and $\mathrm{O}_{3}$ \\
\hline 3 & 117.24 & $\mathrm{E}$ & Stretching vibrations $\mathrm{Bi}$ and $\mathrm{O}_{2}$ \\
\hline 4 & 132.70 & A & $\mathrm{Bi}$ and $\mathrm{O}_{2}$ vibration \\
\hline 5 & 159.66 & A & Vibration of $\mathrm{Bi}$ and all $\mathrm{O}$ atoms \\
\hline 6 & 194.35 & $\mathrm{~T}$ & $\begin{array}{l}\text { Stretching of } \mathrm{Bi}-\mathrm{O}_{2} \text {, deformation of } \mathrm{Bi}-\mathrm{O}_{2}-\mathrm{Bi} \text { and weak } \\
\qquad \mathrm{Bi}-\mathrm{O} 1 \text { rocking }\end{array}$ \\
\hline 7 & 245.006 & A & $\mathrm{Bi}-\mathrm{O} 1$ rocking and weak stretching vibration $\mathrm{O}_{2}$ \\
\hline 8 & 301.82 & A & Vibration of $\mathrm{O}_{2}$ atoms and weak $\mathrm{Bi}-\mathrm{O}_{1}$ rocking \\
\hline 9 & 368.15 & $\mathrm{~T}$ & Deformation of $\mathrm{O}_{1}-\mathrm{Bi}-\mathrm{O}_{2}$ and $\mathrm{O}_{1}-\mathrm{Bi}-\mathrm{O}_{3}$ \\
\hline 10 & 521.74 & A & Vibration of $\mathrm{O}_{1}$ atoms \\
\hline 11 & 616.30 & $\mathrm{E}$ & Stretching vibrations $\mathrm{O}_{3}$ and weak $\mathrm{Bi}-\mathrm{O}_{1}$ and $\mathrm{Bi}-\mathrm{O}_{2}$ rocking \\
\hline 12 & 818.59 & FTO & Antisymetric stretching vibration of $\mathrm{TiO}_{4}$ tetraedra \\
\hline
\end{tabular}

Indium oxide usually absorbs 800-300 $\mathrm{cm}^{-1}$ radiation ${ }^{23}$. In our compound (Fig.8), a peak at 818.59 $\mathrm{cm}^{-1}$ is actually observed and therefore attributed to the In- $\mathrm{O}_{4}$ tetrahedra.

The shoulder observed at about $368.15 \mathrm{~cm}^{-1}$ is probably assigned to $\mathrm{Bi}-\mathrm{O}-\mathrm{In}$ bonds because the mass of bismuth is higher than that of indium. As a result, the oscillations of In- $\mathrm{O}_{4}$ tetrahedra are small.

Peaks observed at 117.24 and $301.82 \mathrm{~cm}^{-1}$ frequency are due to symmetrical vibrations of $\mathrm{Bi}-\mathrm{O} 1 / \mathrm{O}_{2}$.

Peaks below $616.30 \mathrm{~cm}^{-1}$ are mainly attributed to $\mathrm{Bi}$ $\mathrm{O}$ vibrations. The set of frequency attributions observed is shown in Table 5. In agreement with the crystalline structure, the $\mathrm{MO}_{4}$ tetrahedra are surrounded by 12 Bismuth atoms, and thus the displacements of these tetrahedra are weak.

It seems that the IR mode relating to bismuth (high mass) must indeed move to the low frequencies; it is not indistinguishable from other lattice vibrations. The constant force $\mathrm{Bi}-\mathrm{O}$ is therefore strong. Moreover, the frequencies $v 3$ of the $\mathrm{InO}_{4}$ and $\mathrm{BiO}_{4}$ tetrahedra are lowered approximatively by $50 \mathrm{~cm}^{-1}$ to those observed in ions. This effect is attributed to the existence of Bi-O-In bonds with tetrahedral sites by $\mathrm{M}^{3+}$.

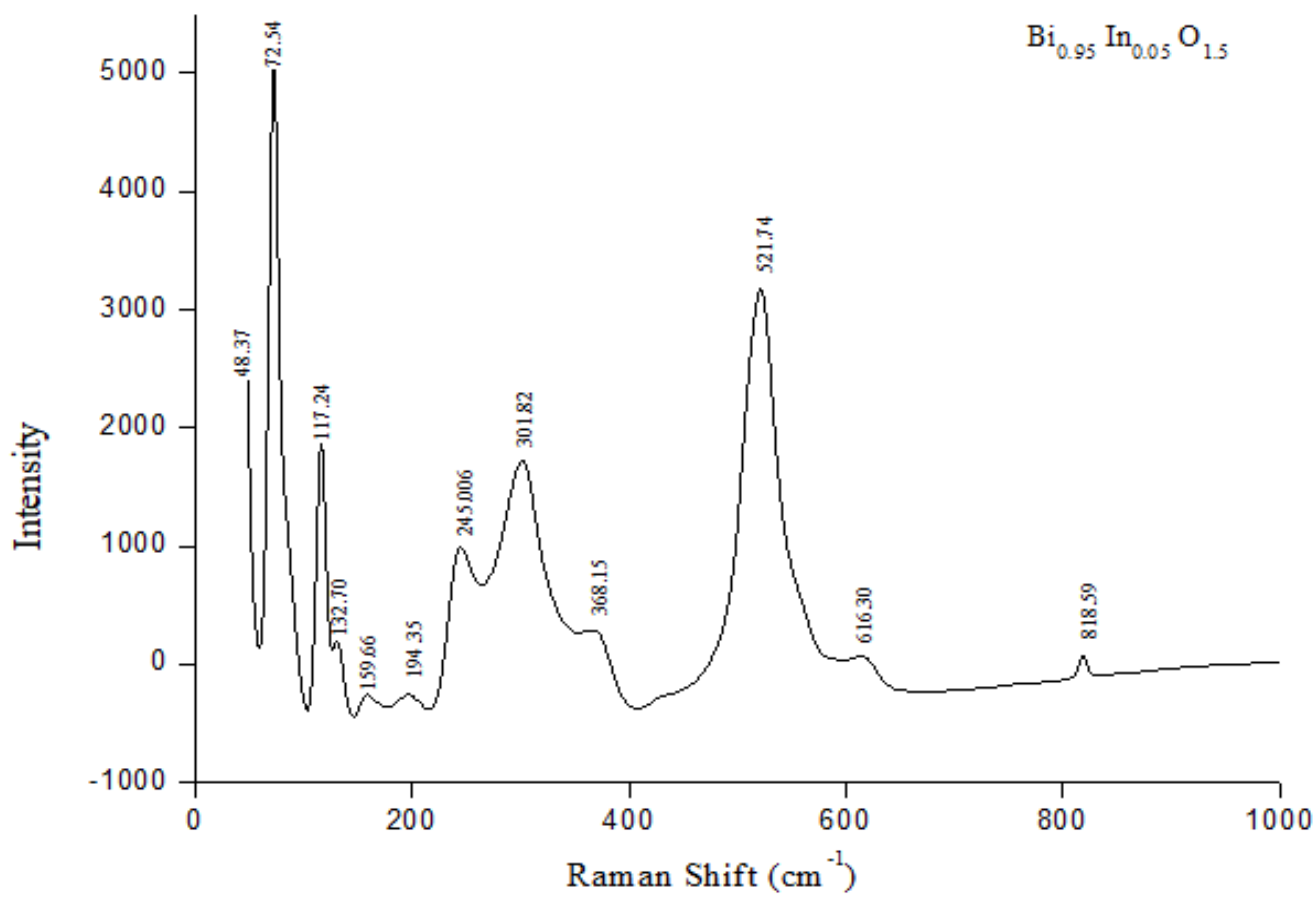

Figure 8. Raman spectrum of $\mathrm{Bi}_{0.95} \operatorname{In}_{0.05} \mathrm{O}_{1.5}$ 


\subsection{Infrared spectroscopy analysis}

IR spectrum of the crystal $\mathrm{Bi}_{0.95} \mathrm{In}_{0.05} \mathrm{O}_{1.5}$ is illustrated in the Figure. 9. The significant band frequencies of $\mathrm{Bi}_{0.95} \mathrm{In}_{0.05} \mathrm{O}_{1.5}$ are given in Table 6. The bands

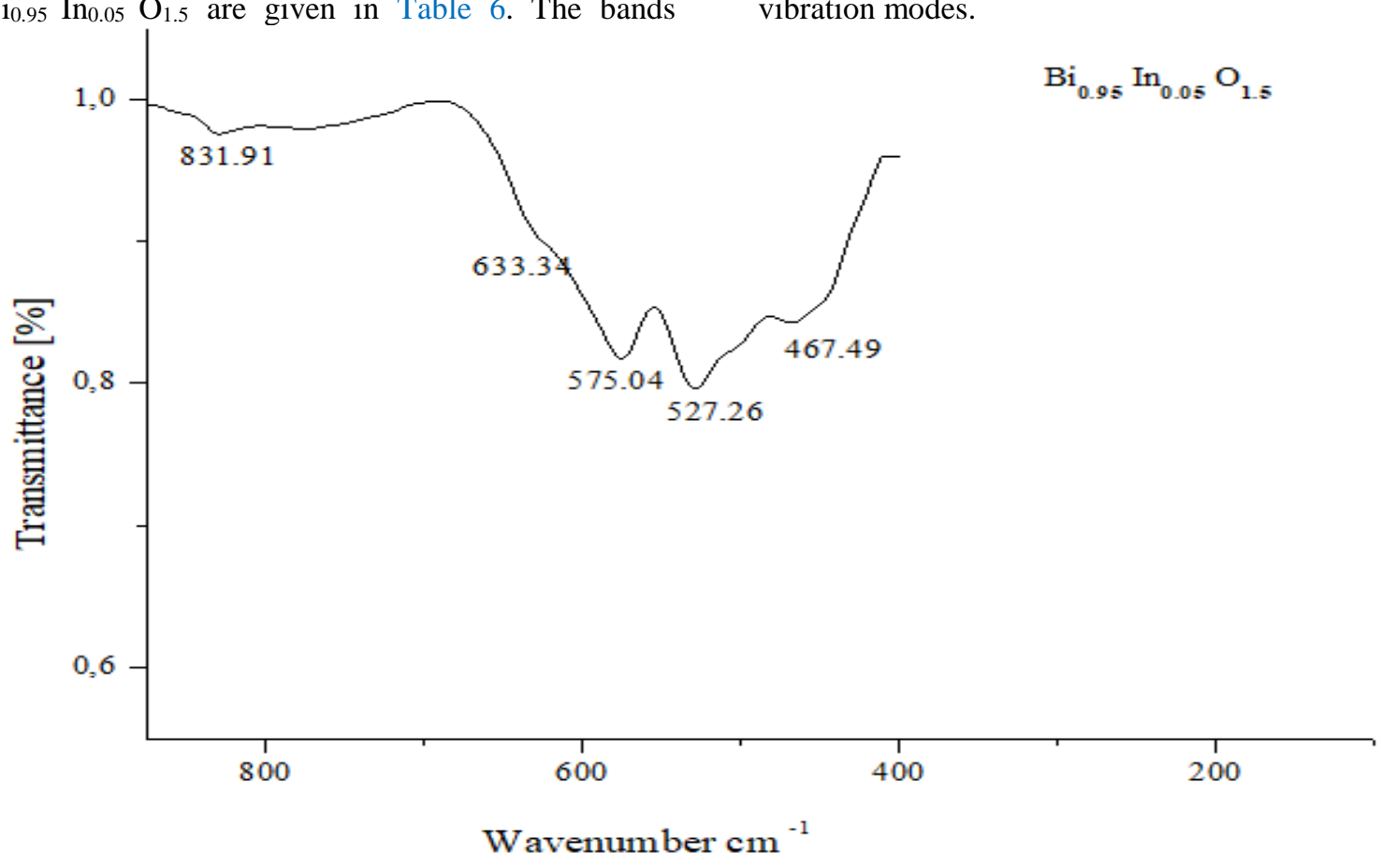

observed between 467.49 and $633.34 \mathrm{~cm}^{-1}$ are attributed to $\mathrm{Bi}-\mathrm{O}$ vibration modes. The one that appeared at $831.91 \mathrm{~cm}^{-1}$ is assigned to the $\mathrm{Bi}-\mathrm{O}-\mathrm{Bi}$ vibration modes.

Figure 9. IR spectrum of $\mathrm{Bi}_{0.95} \mathrm{In}_{0.05} \mathrm{O}_{1.5}$

Table 6. band frequencies of $\mathrm{Bi}_{0.95} \operatorname{In}_{0.05} \mathrm{O}_{1.5}$.

\begin{tabular}{|c|c|c|}
\hline Our work & Ref $^{25}$ & Attribution \\
\hline Bio.95 Ino.05 O1.5 & 457 & Vibration mode of Bi-O \\
\hline $\mathbf{4 6 7 . 4 9}$ & 535 & \\
\hline $\mathbf{5 2 7 . 2 6}$ & 586 & \\
\hline $\mathbf{5 7 5 . 0 4}$ & 663 & \\
\hline $\mathbf{6 3 3 . 3 4}$ & - & Vibration mode of Bi-O-Bi \\
\hline $\mathbf{8 3 1 . 9 1}$ & & \\
\hline
\end{tabular}

\section{Conclusion}

The results of structural refinements are in perfect agreement with those determined by ${ }^{16,17}$ on sillenite compounds. The structure is formed by a sequence of $\mathrm{BiO}_{5}$ polyhedra linked together by edges. These polyhedra are connected by $\mathrm{Bi} / \mathrm{InO}_{4}$ tetrahedra via $\mathrm{O}_{3}$ atoms.

The phases are non-stoichiometric on both the anion and cation sublattice. They are similar to $\gamma \mathrm{Bi}_{2} \mathrm{O}_{3}$ type sillenite phase. The substitution of $\mathrm{Bi}$ by $\mathrm{In}$ of a smaller size causes a lattice parameter decrease. Three regions are elucidated by the vibrational spectroscopic study. The low-frequency region is attributed to cations displacement, the second region, which corresponds to medium frequencies, is attributed to stretching vibration modes of $\mathrm{Bi}-\mathrm{O}$ however, the high frequencies (observed in the third region) are assigned to the deformation bonds of $\mathrm{Bi} / \mathrm{In}-\mathrm{O}-\mathrm{Bi}$.

\section{References}

1- S. Iyyapushpam, S. T. Nishanthi, D. Pathinettam Padiyan, Enhanced photocatalytic degradation of methyl orange by gamma $\mathrm{Bi} 2 \mathrm{O} 3$ and its kinetics, J Alloys Compd, 2014, 601, 85-87.

2- S. Y. Chai, Y. J. Kim, M. H. Jung, A. K. Chakraborty, D. Jung, W. I. Lee, Heterojunctioned $\mathrm{BiOCl} / \mathrm{Bi}_{2} \mathrm{O}_{3}$, a new visible light photocatalyst, J Catal, 2009, 262, 144-149.

3- J. Zeng, J. Li, J. Zhong, S. Huang, W. Shi, J. He, Synthesis, characterization and solar photocatalytic performance of $\mathrm{In}_{2} \mathrm{O}_{3}$-decorated $\mathrm{Bi}_{2} \mathrm{O}_{3}$, Mater Sci Semicond Process, 2013, 16, 1808-1812.

4- J. Eberl, H. Kisch, Visible light photo-oxidations in the presence of $\alpha-\mathrm{Bi}_{2} \mathrm{O}_{3}$, Photochem Photobiol Sci, 2008, 7, 1400.

5- H.-Y. Jiang, K. Cheng, J. Lin, Crystalline metallic Au nanoparticle-loaded $\alpha-\mathrm{Bi}_{2} \mathrm{O}_{3}$ 
microrods for improved photocatalysis, Phys Chem Chem Phys, 2012, 14, 12114.

6- Z. Ai, Y. Huang, S. Lee, L. Zhang, Monoclinic $\alpha-\mathrm{Bi}_{2} \mathrm{O}_{3}$ photocatalyst for efficient removal of gaseous $\mathrm{NO}$ and $\mathrm{HCHO}$ under visible light irradiation, J Alloys Compd, 2011, 509, 2044-2049.

7- I. F. Vasconcelos, M. A. Pimenta, A. S. B. Sombra, Optical properties of $\mathrm{Bi}_{12} \mathrm{SiO}_{20}$ (BSO) and $\mathrm{Bi}_{12} \mathrm{TiO}_{20}$ (BTO) obtained by mechanical alloying, J Mater Sci, 2001, 36, 587-592.

8- M. Mesrar, T. Lamcharfi, N.-S. Echatoui, F. Abdi, F. Z. Ahjyaje, M. Haddad, Effect of barium doping on electrical and electromechanical properties of (1-x) $\left(\mathrm{Na}_{0.5} \mathrm{Bi}_{0.5}\right) \mathrm{TiO}_{3}-\mathrm{xBaTiO}_{3}$, MediterrJChem, 2019, 8, 198.

9- H. AitOulahyane, L. Loubbidi, A. Chagraoui, L. Bourja, S. Villain, O. Ait Sidi Ahmed, A. Moussaoui, A. Menichi, Structural, Electrical and Morphological Properties of Materials Type Sillenite Phase $\mathrm{Bi}_{12} \mathrm{TiO}_{2} 0$, Chemistry Africa, 2019, 2, 57-66.

10-E. M. Levin, R. S. Roth, Polymorphism of bismuth sesquioxide. II. Effect of oxide additions on the polymorphism of $\mathrm{Bi}_{2} \mathrm{O}_{3}$, J Res Natl Bur Stan Sect A, 1964, 68A, 197.

11-S. F. Radaev, V. I. Simonov, Yu. F. Kargin, Structural features of $\gamma$-phase $\mathrm{Bi} 2 \mathrm{O} 3$ and its place in the sillenite family, Acta Crystallogr B Struct Sci, 1992, 48, 604-609.

12-S. F. Radaev, L. A. Muradyan, V. I. Simonov, Atomic structure and crystal chemistry of sillenites: $\mathrm{Bi}_{12}\left(\mathrm{Bi}^{3+}{ }_{0.50} \mathrm{Fe}^{3+}{ }_{0.50}\right) \mathrm{O}_{19.50}$ and $\mathrm{Bi}_{12}\left(\mathrm{Bi}^{3+}{ }_{0.67} \mathrm{Zn}^{2+}{ }_{0.33}\right) \mathrm{O}_{19.33}$, Acta Crystallogr B Struct Sci, 1991, 47, 1-6.

13-M. Valant, D. Suvorov, A Stoichiometric Model for Sillenites, Chem Mater, 2002, 14, 3471-3476.

14-A. Watanabe, S. Takenouchi, P. Conflant, J.-P. Wignacourt, M. Drache, J.-C. Boivin, Preparation of a Nonstoichiometric Sillenite-Type Phase in the System $\mathrm{Bi}_{2} \mathrm{O}_{3}-\mathrm{As}_{2} \mathrm{O}_{5}$, Journal of Solid State Chemistry, 1993, 103, 57-62.

15-T. H. Noh, S. W. Hwang, J. U. Kim, H. K. Yu, H. Seo, B. Ahn, D. W. Kim, I. S. Cho, Optical properties and visible-light-induced photocatalytic activity of bismuth sillenites
$\left(\mathrm{Bi}_{12} \mathrm{XO}_{20}, \mathrm{X}=\mathrm{Si}, \mathrm{Ge}, \mathrm{Ti}\right)$, Ceram Int, 2017, 43, 12102-12108.

16-S. F. Radaev, V. I. Simonov, Y. F. Kargin, V. M. Skorikov, New data on structure and crystal chemistry of sillenites Bi12MxO20 $\pm \delta$, Eur $J$ Solid State Inorg Chem, 1992, 29, 383-392.

17-J.-C. Champarnaud-Mesjard, B. Frit, A structural model for the $\mathrm{Bi} 1-\mathrm{xCdxO} 1.5-\mathrm{x} / 2(0 \leq \mathrm{x} \leq$ 0.0256) sillenite-type solid solution, $C R$ Acad Sci Paris, $t$ 2, Série II c, 1999, 2, 369-374.

18-Program Full Prof.2k (Version 5.30 - Mar2012ILL JRC).

19-Y. Hu, D. C. Sinclair, Relaxor-like Dielectric Behavior in Stoichiometric Sillenite $\mathrm{Bi}_{12} \mathrm{SiO}_{20}$, Chem Mater, 2013, 25, 48-54.

20-R. D. Shannon, Revised effective ionic radii and systematic studies of interatomic distances in halides and chalcogenides, Acta Cryst A, 1976, 32, 751-767.

21-V. I. Burkov, V. S. Gorelik, A. V. Egorysheva, Y. F. Kargin, Laser Raman Spectroscopy of Crystals with the Structure of Sillenite, J Russ Laser Res, 2001, 22, 25.

22-A. V. Egorysheva, V. I. Burkov, Y. F. Kargin, V. G. Plotnichenko, V. V. Koltashev, E. D. Obraztsova, S. V. Terekhov, Atomic Structure Features of Sillenite Crystals as Probed by Raman Spectroscopy, Russ J Inorg Chem, 2005, 50, 238-245.

23-I. J. Panneerdoss, S. J. Jeyakumar, S. Ramalingam, M. Jothibas, Characterization of prepared $\mathrm{In}_{2} \mathrm{O}_{3}$ thin films: The FT-IR, FT-Raman, UV-Visible investigation and optical analysis, Spectrochim Acta, Part A, 2015, 147, 1-13.

24-B. Mihailova, M. Gospodinov, L. Konstantinov, Raman spectroscopy study of sillenites. I. Comparison between $\mathrm{Bi}_{12}(\mathrm{Si}, \mathrm{Mn}) \mathrm{O}_{20}$ single crystals, Journal of Physics and Chemistry of Solids, 1999, 60, 1821-1827.

25-X. Zhu, J. Zhang, F. Chen, Study on visible light photocatalytic activity and mechanism of spherical Bi12TiO20 nanoparticles prepared by low-power hydrothermal method, Applied Catalysis B: Environmental, 2011, 102, 316-322.

26-Zs. Szaller, L. Kovács, L. Pöppl, Comparative Study of Bismuth Tellurites by Infrared Absorption Spectroscopy, J Solid State Chem, 2000, 152, 392-396. 